$\xi=-1$

\title{
Development and Effectiveness of Interactive Learning Media For Mathematical Logic and Set Towards Students' Self Confident on Computer.
}

\author{
Syariful Fahmi ${ }^{1 *}$, Soffi Widyanesti Priwantoro², Rima Aksen Cahdriyana ${ }^{3}$ \\ ${ }^{1,2,3}$ Mathematics Education, Universitas Ahmad Dahlan, Yogyakarta, Indonesia \\ *Corresponding author E-mail:syariful.fahmi@pmat.uad.ac.id
}

\begin{abstract}
This research aims to find out how to develop and produce interactive learning media using Adobe Flash CS3 for students of mathematics education in the course of mathematical logic and Set in class D academic year of 2017/2018, as well as how the quality of the resulting learning media. The population in this research is the entire class D in first semester student in Mathematics Education academic year of 2017/2018. The model used is the development model of Borg and Gall which includes: (1) analysis of the content standards, (2) the collection of references to interactive media, (3) the preparation of draft interactive media, and (4) creation of interactive media in the form of digital discs (CD). Interactive multimedia has produced score of good quality according to the assessment of the learning material experts, media experts, and students of Class D academic year of 2017/2018, with an average score was 209.48 with maximum score of 260. The effectiveness toward students' confidents on computer shows there, $73.81 \%$ of students feel able to get good grades if learning with computers, $57.14 \%$ of students feel very confident when starting to learn with computers, and $50 \%$ students learn to feel confident with computers.
\end{abstract}

Keywords: Developments; Effectiveness; Interactive Learning Media; Mathematical Logic and Set; Students' Self Confident on Computer.

\section{Introduction}

Aspects in learning mathematics are the most important skills in the process was stressed thinking. Students are trained to be able to develop the ability of logical thinking, analytical, systematic and consistent. To assist in the process of thinking, or animated images and can be used. In the planning of learning lecturer can enrich the material to be conveyed by taking several contextual examples that exist in the virtual world with the help of the internet.

"Indonesian Educational Ministery [4]" released that all of schools have had ICT equipment especially computer and its network for increasing the competence of graduates' purpose, either in the classroom or in the library and laboratories. The computer can be used as media in learning mathematics. The computer could present in the form of graphics and media audio video. Of course this adds an attraction for students in learning, so the boring presentation on teaching lectures can be reduced.

Mathematical logic and set is one of the objects in UAD mathematics education study programs who has its own difficulties. One of the material in mathematical logic and set is the students ask to determine the truth of a single statement, which is sometimes make the students confuse. So it is very necessary to use the media that could explain more real, as well as provide simulationsimulation to train and improve the understanding of the students. One of the ICT products that can be used in the learning process is Adobe Flash CS3 (formerly Macromedia Flash Professional 8). With this software not only makes a presentation of learning, but it can develop interactive learning where students are learning with display has been prepared. In this learning process, students will choose and goes step by step, starting from the opening, the point material to the evaluation question. Adobe Flash CS3 is one of the animation design software maker. "Deniz et al [3]" have declared this software is very popular and has been recognized sophistication and completeness of facilities that are able to create animated design, making this software most widely used by computer designers.

"Geisert et al [5]" have studied mathematics subject matter in curriculum not all can use computer media, but at least there is new alternative media to support learning mathematics. The use of computers helps teachers become more efficient in completing daily tasks. And more importantly, teachers will experience how computers help with better teaching.

"Yin et al [8]" have discussed a concept that can connect between the development of computers and mathematics learning so that learning mathematics will feel more fun and students can master the subject matter easily. One of the ideas that can be applied is to utilize computer-based media in the process of learning mathematics at school.

Some of the above explanation makes researchers develop learning media using Adobe Flash CS3 in mathematical logic and set courses. Furthermore, interactive multimedia is expected to improve students' self-confidence toward computer.

\section{Method}

This research is research development (Research and Development). "Borg et al [2]" have stated development of the research method is the method of research used to produce a particular product and test the effectiveness of these products. Learning me- 
dia development model used in this study using measures adapted from Borg \& Gall. Borg and Gall [2] developed detailed steps they developed in ten steps: (1) research and information collecting, (2) planning, (3) developing preliminary form of product, (4) preliminary field testing, (5) main product revision, (6) main field testing, (7) operational product revision, (8) operational field testing, (9) final product revision, (10) dissemination and implementation. The details as follows:

a. Introduction

1. The study of the literature, that examines the theories and results of relevant research in accordance with the research and development that will be carried out

2. Analyze the needs and characteristics of the program.

3. Field study to find out and prepare the needs needed in conducting research.

b. Development

1. Determine the standards of competence, basic competence, the indicator and the subject matter will be presented.

2. Preparing Learning Media containing teaching materials and assessment instruments.

3. Develop research instruments which include: questionnaires for experts, student questionnaires, and observation sheets.

c. Validation

1. Experts Test Development

Conduct early tests on product design by mathematicians, mathematical material experts, media experts.

2. Small Group Test

Small group tests are conducted to determine the effectiveness of product design. The trial was conducted on students who represented groups with high, medium and poor abilities. The test results are in the form of an effective design, both in terms of substance and methodology.

3. Field trials and feasibility

Tests conducted on students in one class.

Table 1 show Percentage Score interval of Student Confidence on Computer to know the criteria of percentage of students' selfconfidence score on mathematics and ICT.

Table 1: Percentage Score interval of Student Confidence on Computer

\begin{tabular}{|l|l|l|}
\hline No & Percentage of mastery & Qualitative Criteria \\
\hline 1 & $\mathrm{q} \geq 80 \%$ & Very Good \\
\hline 2 & $10 \% \leq \mathrm{q}<80 \%$ & Good \\
\hline 3 & $40 \%<\mathrm{q} \leq 60 \%$ & Enough \\
\hline 4 & $20 \%<\mathrm{q} \leq 40 \%$ & Bad \\
\hline 5 & $\mathrm{q} \leq 20 \%$ & Very Bad \\
\hline
\end{tabular}

Where $\mathrm{q}=$ Percentage of students confident score on computer. Interactive multimedia said to be effective if the percentage of students' self-confidence score on computer in post test has a percentage of more than $40 \%$ of students expressed no anxiety with computer or at least have "enough" criteria.

\section{Result and Discussions}

This research has managed to develop interactive learning media with steps:

\subsection{Interactive learning media development}

Research development of this was done through the steps as follows:

\subsubsection{Planning}

1) On the planning phase was carried out by the study of literature and the study of the field. The study of literature done by analyse the material that will be made in the form of a learning $\mathrm{CD}$, and retrieved the material of math logic and set that includes a compound statement and the statement, the withdrawal of the conclu- sions in the laboratory computers in mathematics education UAD, observations on the students in learning mathematics. The number of computers owned by the mathematics education lab is $30 \mathrm{com}-$ puters, and students can use one computer to one of the students, where computers are available at a minimum meet the minimum specifications as follows:

a) Windows XP operating system.

b) Processor Intel Pentium III $600 \mathrm{MHz}$ up to the latest.

c) RAM $512 \mathrm{MB}$

2) Plan and choose the type of media content will be used. The selected learning media, namely in the form of CD (Digital Disk/Compact Disk) learning that can be used with any computer.

3) Collecting the references. At this stage the researcher is looking for and collect references that support the research. References in the form of print media (book) or digital (e-book). The book used, among others:

a). Drs. Sukirman, M. Pd. book titles with logic and Set

b). Drs Ibnu Ngathoillah with the title of the book mathematical logic and the set

\subsubsection{Design}

At the stage of design, measures undertaken include:

1) Analysis of the content of the curriculum. At this stage done by sorting material mathematical logic and set for pass through the medium of interactive learning. Such material be removed from the source books which reference by researchers. The material had already been drawn up is used as the content of the media learning plan is then inserted into the material of the medium of instruction. 2) Drafting the Story board of the learning media. Story board of learning media compiled for ease in making learning and media as a learning medium making peruses.

3) Setting up the music, making videos and voice in the media of instruction. Music used in this study is media music accompaniment so that students don't feel saturated when learning. The volume of music has its own settings so that it can be tailored to the needs of the students. In addition to setting up the music, the researchers also prepares related contextual video material, where this video researchers create their own material needs. To clarify the matter, the researchers also provided the voice of the companion on the learning media.

In addition to software and hardware needs, at this stage of the development of learning $\mathrm{CD}$ also includes:

1) Making learning CD components using adobe flash CS3. Create animated image is required, create the buttons and makes writing or text in titles, subtitles and other writings.

2) Create interactive multimedia in accordance with designs made from ingredients that have been collected. In this stage done some stage development, include making a learning achievement display that must be mastered by students before learning the material, making a display of instructions for using learning CDs, making the contents of learning media material, making tasks and evaluation displays to provide evaluation after learning to use $\mathrm{CD}$, Creating Profile display. This profile display contains data about the learning $\mathrm{CD}$ compiler, and also making minimize, maximize, and exit display. The creation of this display aims to enable students or users to reduce the appearance, expand the appearance and exit the learning media. The appearance is as follows in figure 1 and figure 2 :

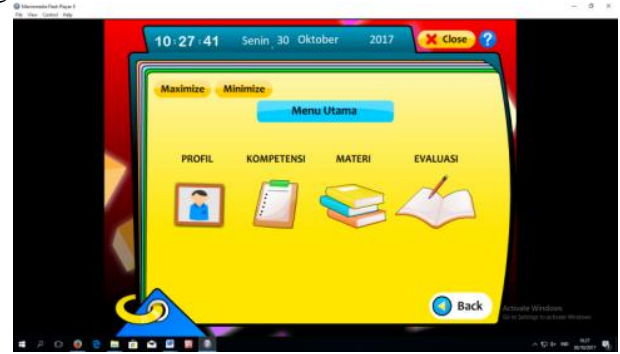

Fig. 1: Menu Display 


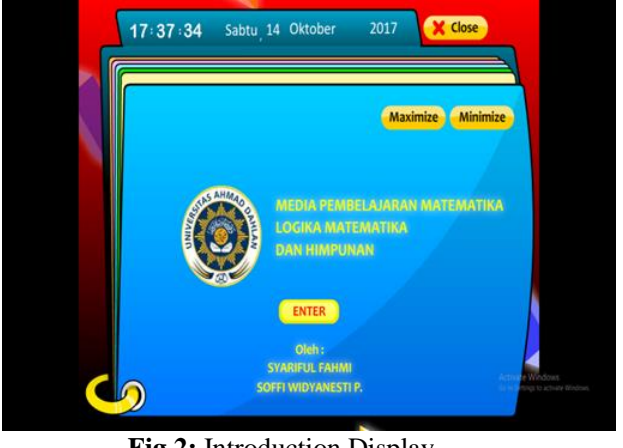

Fig.2: Introduction Display

\subsubsection{Validation of learning media.}

Conducted learning $\mathrm{CD}$ validation for 1 material and learning expert, and 1 media expert, 6 students in small class test, and 20 students in large class test using learning media quality assessment instrument consisting of questionnaires and observation sheets that were validated by experts. The research instrument sheet consisted of 51 statements, with 13 statements on aspects of education assessed by material and learning experts, 19 statements on aspects of multimedia display that were assessed by media experts, and 19 indicators on technical aspects assessed by students. "Urip [7]" declared the questionnaires of multimedia adapted by Indonesian Department of Education and Culture. Table 1 shown the aspects of education assessed by material and learning experts.

Table 1: Aspects of education assessed by material and learning experts.

\begin{tabular}{|c|c|}
\hline No & Aspect \\
\hline 1 & Clarity of learning objectives in multimedia \\
\hline 2 & $\begin{array}{l}\text { The linkage of learning objectives in multimedia with the curric- } \\
\text { ulum }\end{array}$ \\
\hline 3 & Suitability between material and media with learning objectives \\
\hline 4 & Theoretical and concept truths \\
\hline 5 & Completeness and depth of material in multimedia \\
\hline 6 & $\begin{array}{l}\text { Clarity of material description, discussion, examples, simula- } \\
\text { tions, exercises }\end{array}$ \\
\hline 7 & $\begin{array}{l}\text { Linkages and consistency of evaluation tools with learning ob- } \\
\text { jectives }\end{array}$ \\
\hline 8 & Suitability of feedback on training and evaluation results \\
\hline 9 & $\begin{array}{l}\text { The link between the material taught with the real world situa- } \\
\text { tion }\end{array}$ \\
\hline 10 & $\begin{array}{l}\text { The ability to encourage students to make a connection between } \\
\text { their knowledge and its application in daily life }\end{array}$ \\
\hline 11 & Clarity of questions in encouraging students' thinking skills. \\
\hline 12 & $\begin{array}{l}\text { Clarity of sample questions and how to solve them (modeling) } \\
\text { are used to facilitate understanding of the concept }\end{array}$ \\
\hline 13 & $\begin{array}{l}\text { Accuracy of summary / reflection examples of procedure prob- } \\
\text { lems and how to solve them. }\end{array}$ \\
\hline
\end{tabular}

The aspects of multimedia that were assessed by media experts shown in Table 2 below.

Table 2: Aspects of multimedia assessed by media experts.

\begin{tabular}{|c|l|}
\hline No & \multicolumn{1}{c|}{ Aspect } \\
\hline 1 & Creativity and innovation in multimedia \\
\hline 2 & Truth and suitability of language \\
\hline 3 & $\begin{array}{l}\text { Advantages of learning multimedia compared to conventional } \\
\text { learning presentations }\end{array}$ \\
\hline 4 & Suitability of multimedia with social values \\
\hline 5 & Clarity of multimedia usage instructions \\
\hline 6 & Effectiveness and efficiency in use \\
\hline 7 & Accuracy of Multimedia response to user input (Interactivity) \\
\hline 8 & $\begin{array}{l}\text { The accuracy of the selection of application / multimedia / tool } \\
\text { types for development }\end{array}$ \\
\hline 9 & Ease of multimedia maintenance \\
\hline 10 & Ease of operation \\
\hline 11 & Easy installation in the device (compatibility) \\
\hline 12 & Integrated learning multimedia packaging and ease of execution \\
\hline 13 & $\begin{array}{l}\text { The use of a harmonious, complete and similar visual and audio } \\
\text { language in supporting the material }\end{array}$ \\
\hline
\end{tabular}

\begin{tabular}{|c|l|}
\hline 14 & $\begin{array}{l}\text { The accuracy of color selection to support the compatibility } \\
\text { between creative concepts and material }\end{array}$ \\
\hline 15 & Font accuracy and arrangement of letters (Typography) \\
\hline 16 & Accuracy of layout: laying and arrangement of visual elements \\
\hline 17 & The accuracy of the use of visual elements \\
\hline 18 & Navigation accuracy (panel buttons) \\
\hline 19 & Compatibility of audio elements \\
\hline
\end{tabular}

Assessment of student aspects (technical aspects) which includes aspects of user reaction (feeling of pleasure, boredom, and motivation), multimedia display (attractive appearance, layout, and color suitability), presentation of material and contextuality, ease of use (starting program and instructions for use) and interactivity multimedia.

Based on the overall ideal assessment criteria, both the assessment of material and learning experts, media experts, and student assessments, obtained the quality of multimedia learning from all aspects of assessment that is equal to 209.48 of a maximum score of 260 so that multimedia learning gets a good assessment and can be used as a learning resource for mathematics logic and set courses.

\subsection{Students' self-confidence on the computer}

In addition to developing interactive multimedia, this research is also to know how confident students to computers before learning with multimedia and after the learning process is completed using multimedia. The students' attitude toward computer instruments was based on attitude survey on computer (Computer Attitude Survey / CAS) according to Loyd and Gressard (1984), and improved by Dorotthy J Laubscher (2010) [6].

Table 3: Students' self-confidence score on the computer

\begin{tabular}{|ll|l|}
\hline \multicolumn{3}{|c|}{ Table 3: Students' self-confidence score on the computer } \\
\hline \multicolumn{1}{|c|}{ Category } & Percentage \\
\hline 1. & Confidence when learning with computer & $50.00 \%$ \\
\hline 2. & $\begin{array}{l}\text { Able to get good grades if studying with a com- } \\
\text { puter }\end{array}$ & $73.81 \%$ \\
\hline 3. & $\begin{array}{l}\text { Be confident when starting to learn with com- } \\
\text { puter }\end{array}$ & $57.14 \%$ \\
\hline
\end{tabular}

The Table 3 is a table of students' self-confidence score on the computer. Based on the table, it can be seen that the percentage of students' self-confidence to computer shows there are $73,81 \%$ students feel able to get good value if studying with computer, $57,14 \%$ student feel very confident when start study with computer, and $50 \%$ student feel confident studying with computer. Literature reveals the range or scope of factors affecting mathematics learning achievement, such as access to ICT, use of home computers or at school and socio-economic status of a person. The results of this study support what has been proposed by Thomson in PISA 2003 (Program for International Student Assessment), that when teachers use computers in learning mathematics, students will better understand mathematics materials compared with other lessons [1].

\section{Conclusion}

The conclusion obtained is the quality of Adobe Flash CS3-based learning media in mathematical logic and set courses in the good category, so it is feasible to be used for mathematical logic and set learning, whether in the classroom or self-study and a change in students' self-confidence, by looking at posttest results against pretest. The changes include the aspect of students feeling able to get good grades when learning with computers, students feel very confident when they start learning with computers, and students feel confident learning by computer. 


\section{Acknowledgement}

The author thanks Faculty of Teacher Training and Education, Universitas Ahmad Dahlan for the funding of cost of publication for this research.

\section{References}

[1] Bhagat KK \& Chang CY (2014), Eurasia. Journal of Mathematics, Science \& Technology Education 11, 77-86.

[2] Borg, WR \& Gall MD (1983), Educational reseacher: an introduction, fourth edition. New York: Longman.

[3] Deniz O \& Uygur-Kabael T (2017), H.U. Journal of Education 32, 123-142.

[4] Educational Ministery of Indonesia (2006). Towards the development of primary and secondary education management. Jakarta: Director General of Primary and Secondary Education.

[5] Geisert PG \& Futrell MK (1995), Teachers, komputer, and curriculum. Boston: Allyn and Bacon.

[6] Laubscher JD (2010), Mathematics Teacher-Students' Attitude toward Information and Communication Technology across Three Country. Potchefstroom Campus of the North-West University.

[7] Purwono U (2008), Standar Penilaian Buku Pelajaran. http://telaga.cs.ui.ac.id/ heru/bsnp/13oktober08/Bahan\%20Sosialis asi\%20Standar\%20Penilaian\%20Buku\%20Teks\%20Pelajaran\%20 TIK.ppt.

[8] Yin TS, Ahmada A, Fang LY, Yen YH \& How KW (2010), Incorporating Multimedia as a Tool into Mathematics Education: A Case Study on Diploma Students in Multimedia University. Procedia Social and Behavioral Sciences 8, 594-599. 